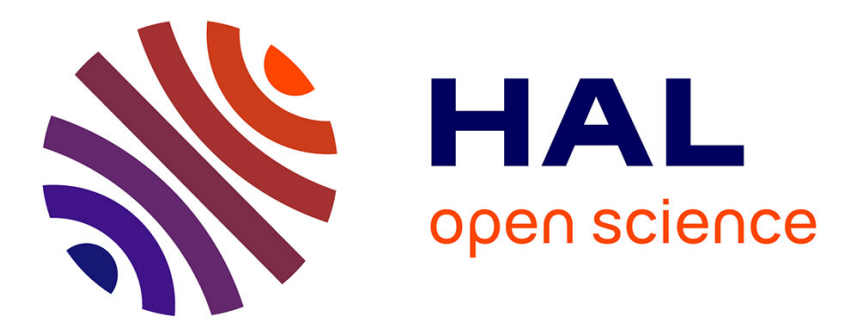

\title{
Organic phosphorus in atmospheric deposition over the Mediterranean Sea: An important missing piece of the phosphorus cycle
}

Kalliopi Violaki, François Bourrin, Laurence Voutquenne-Nazabadioko, Giorgos Kouvarakis, Nicole Delsaut, Nikos Mihalopoulos

\section{To cite this version:}

Kalliopi Violaki, François Bourrin, Laurence Voutquenne-Nazabadioko, Giorgos Kouvarakis, Nicole Delsaut, et al.. Organic phosphorus in atmospheric deposition over the Mediterranean Sea: An important missing piece of the phosphorus cycle. Progress in Oceanography, 2018, 163, pp.50-58. hal-02042956

\section{HAL Id: hal-02042956 https://hal.science/hal-02042956}

Submitted on 5 Mar 2019

HAL is a multi-disciplinary open access archive for the deposit and dissemination of scientific research documents, whether they are published or not. The documents may come from teaching and research institutions in France or abroad, or from public or private research centers.
L'archive ouverte pluridisciplinaire HAL, est destinée au dépôt et à la diffusion de documents scientifiques de niveau recherche, publiés ou non, émanant des établissements d'enseignement et de recherche français ou étrangers, des laboratoires publics ou privés. 


\title{
Organic phosphorus in atmospheric deposition over the Mediterranean Sea: An important missing piece of the phosphorus cycle
}

\author{
Kalliopi Violaki ${ }^{\mathrm{a}, \mathrm{b}, *}$, François Bourrin ${ }^{\mathrm{c}}$, Dominique Aubert ${ }^{\mathrm{c}}$, Giorgos Kouvarakis ${ }^{\mathrm{a}}$, Nicole Delsaut ${ }^{\mathrm{d}}$, \\ Nikos Mihalopoulos ${ }^{\mathrm{a}, \mathrm{e}, *}$ \\ ${ }^{a}$ Environmental Chemistry Processes Laboratory, Department of Chemistry, University of Crete, P.O. Box 2208, 71003 Heraklion, Greece \\ ${ }^{\mathrm{b}}$ Aix-Marseille University, Mediterranean Institute of Oceanography (MIO) UMR 7294, University de Toulon, CNRS, IRD, France \\ c University of Perpignan Via Domitia (UPVD), CEFREM, UMR5110, F-66860 Perpignan, France \\ d CNRS, CEFREM, UMR5110, F-66860 Perpignan, France \\ e Institute for Environmental Research and Sustainable Development, National Observatory of Athens, Pendeli, Greece
}

\begin{abstract}
A B S T R A C T
To obtain a comprehensive picture of the spatial distribution of atmospheric phosphorus (P) speciation in the Mediterranean Sea, deposition samples were collected from the eastern (E) and north-western (NW) Mediterranean and analyzed for both organic and inorganic P forms. Dissolved P, especially in organic form, is dominant during the wet season, while higher insoluble $\mathrm{P}$ fluxes are recorded during the dry period, mainly due to dust outbreaks. Wet deposition has a significant contribution to the atmospheric phosphorus flux; over the NW Mediterranean accounting for $80 \%$ of the total dissolved phosphorus (TDP). The seven-year average TDP flux during the wet season in the NW basin, of $1.78 \mathrm{mmol} \mathrm{m}^{-2} \mathrm{y}^{-1}$, is almost double that of the two-year average in the eastern Mediterranean. The difference is attributed mainly to the precipitation height being 2-3 times higher in the NW Mediterranean compared to the East. Dissolved organic phosphorus (DOP) is the dominant P fraction in both wet and dry deposition samples, presenting similar fluxes $\left(1.16\right.$ and $0.94 \mathrm{mmol} \mathrm{m}^{-2} \mathrm{y}^{-1}$, in the eastern and north-western basins respectively). Finally, assuming that all TDP is bioavailable, atmospheric deposition of TDP could account for up to $38 \%$ of new production in the eastern Mediterranean, while during oligotrophic periods of the NW Mediterranean it could increase the new production by $14 \%$.
\end{abstract}

\section{Introduction}

Phosphorus is an essential micronutrient for living organisms; it is a part of DNA and RNA molecules and of lipids in cell membranes. Phosphorus can be found on the earth in water, soil, sediments and the atmosphere in both dissolved and particulate pools, in organic and inorganic forms. Phosphorus in the atmosphere is predominantly associated with particulate phase (Vet et al., 2014); however, the presence of gaseous phosphorous compounds such as phosphine and methylphosphine has also been reported in marine and terrestrial atmosphere (Zhu et al., 2007; Han et al., 2010), while the contributions from gaseous organophosphate pesticides (Degrendele et al., 2016) and gaseous organophosphate ester-flame retardants (OPE) (Castro-Jiménez et al., 2016) are not negligible. Inorganic P species (e.g. mono- or diprotonated orthophosphate) are considered the most bioavailable P forms, and the emphasis for many decades has been on the study of their abundance and dynamics. On the other hand, information regarding the chemical speciation of atmospheric organic phosphorus and its role in the biogeochemical cycle of $\mathrm{P}$ in the atmosphere is completely unknown.

In seawater, inorganic phosphorus consists mostly of orthophosphate $\left(\mathrm{PO}_{4}{ }^{3-}\right.$ and $\left.\mathrm{HPO}_{4}{ }^{2-}\right)$, pyrophosphate $\left(\mathrm{H}_{2} \mathrm{P}_{2} \mathrm{O}_{7}{ }^{2-}\right)$ and other condensed inorganic $\mathrm{P}$ compounds, whereas organic phosphorus compounds include mainly nucleic acids, phospholipids, inositol phosphates, phosphoamides, phosphoproteins, phosphonic acids, organophosphate pesticides, humic-associated organic phosphorus compounds, and organic condensed phosphates in dissolved, colloidal and particle-associated forms (Karl and Björkman, 2015). Despite the acknowledged abundance of the organic $P$ fraction in aquatic systems, the importance of this fraction in the atmosphere is not widely recognized.

Aeolian transport of particulate matter from the continents to the open ocean is considered a major pathway for supply of various trace elements, contaminants and nutrients. Strong Sahara events can bring large amounts of particulate matter and associated nutrients (phosphorus and iron) over the Mediterranean Sea (Mermex group, 2011;

\footnotetext{
* Corresponding authors at: Environmental Chemistry Processes Laboratory, Department of Chemistry, University of Crete, P.O. Box 2208, 71003 Heraklion, Greece.

E-mail addresses: kalliopi.violaki@mio.osupytheas.fr (K. Violaki), mihalo@uoc.gr (N. Mihalopoulos).
} 
Richon et al., 2017). Phosphorus is the limiting factor of biological activity in many oligotrophic marine ecosystems, including the eastern Mediterranean Sea (Krom et al., 2004). It is well known that the atmosphere is an important nutrient path, especially for the Levantine basin in the E. Mediterranean and moreover is the dominant nutrient path for $\mathrm{PO}_{4}{ }^{3-}$ compared to the riverine fluxes (Koçak et al., 2010).

The atmospheric deposition of organic P may further influence the primary productivity of the euphotic zone in the Mediterranean, especially in phosphate-limited waters, leading to a greater utilization of the DOP pool, maintaining the production (Mather et al., 2008). The assessment of bioavailability of the organic P pool depends on a number of factors, including the chemical composition, the diversity of the microbial community, the ambient conditions and exposure time (e.g. myo-inositol hexakisphosphate (phytic acid) was hydrolyzed to phosphate within days under typical aerobic marine conditions (Suzumura and Kamatani, 1993)).

In the literature, few studies have reported the presence of organic phosphorous compounds in atmospheric samples. For instance, in rainwater samples collected in New Jersey, 49 organo-phosphorus compounds with structures containing CHONP (29), CHONSP (8), CHOP (7), and CHOSP (5) have been identified (Altieri et al., 2009). Amato et al. (2007) determined an ATP concentration of about $0.40 \mathrm{pmol} \mathrm{mL}^{-1}$ in cloud water, showing that a large majority of cells remain alive in clouds. In $\mathrm{PM}_{10}$ aerosol samples collected in Spain, the presence of organophosphate pesticides Chloropyrifos-e, Chloropyrifos$\mathrm{m}$, Diazinon and Malathion, with mean concentrations of 122, 4, 58 and $12 \mathrm{pg} \mathrm{m}^{-3}$, respectively, has been reported (Coscollà et al., 2011). Finally, Castro-Jiménez et al. (2014) reported 14 different organophosphate ester flame retardant (OPE) compounds with concentration levels, given as $\mathrm{P}$, ranged from 0.04 to $0.8 \mathrm{ng} \mathrm{P} \mathrm{m}^{-3}$ (average value of $0.25 \mathrm{ng} \mathrm{P} \mathrm{m}^{-3}$ ).

Since phosphorus is the limiting factor in many oligotrophic marine environments, valuable information could be gained by defining the relative contribution of organic and inorganic forms of phosphorus in atmospheric deposition. Few studies of atmospheric phosphorus deposition exist and several parts of its global cycle are poorly studied (Vet et al., 2014). There are very few long-term records of phosphorus deposition, which are unevenly distributed in space and time. Besides, comprehensive studies that include all forms of $\mathrm{P}$ do not exist in the literature. In this study, $\mathrm{P}$ speciation was performed in deposition samples, collected from eastern (E) and north-western (NW) Mediterranean Sea, providing a more complete picture of atmospheric deposition of $\mathrm{P}$ species in the Mediterranean.

\section{Experimental methods}

\subsection{Sampling}

\subsubsection{Wet and bulk deposition in East Mediterranean (Greece, Finokalia: $35^{\circ} 20^{\prime} \mathrm{N} 25^{\circ} 40^{\prime} \mathrm{E}$ )}

Rainwater and bulk deposition samples were collected at the Finokalia monitoring station (see Mihalopoulos et al., 1997 for more details) close to a small village on the northern coast of Crete (Fig. 1). Measurements of aerosols and gases performed simultaneously at this sampling site and at airborne and land-based stations during numerous studies (Lelieveld et al., 2002; Markaki et al., 2010) show that measurements at Finokalia are representative of the background eastern Mediterranean atmosphere. This is due both to the location of Crete in the eastern Mediterranean (at the crossroad of the main air masses and fronts influencing the area), as well as to the location of that sampling site (upwind and far from the main cities and tourist resorts of the island).

During a two-year period (2012-2013) rainwater samples $(n=43)$ were collected on an event basis using a wet-only collector installed at Finokalia monitoring station (Fig. 1). Bulk deposition samples $(n=28)$ were also collected in a two-week basis, during the dry period (April-September); hereafter termed dry deposition samples. The estimation of bulk deposition was based on the collection of particles on a flat surface covered by multiple layers of glass beads, which could trap larger particles and avoid resuspension. The glass beads were placed in a funnel installed $3 \mathrm{~m}$ above the ground and exposed to the atmosphere for one to two weeks (Fig. 1). Then the system was washed with ultrapure water $(500 \mathrm{~mL})$. A detailed description of the technique is provided in Kouvarakis et al. (2001).

Immediately after collection the wet and bulk deposition samples were filtered through a pre-weighed $0.45 \mu \mathrm{m}$ cellulose filter. The nonfilterable mass was regarded during this study as insoluble matter. From the filtrated solution three aliquots were obtained. The first was immediately used for $\mathrm{pH}$ determination; to the second, $50-100 \mu \mathrm{L}$ of chloroform were added as a biocide and stored in the refrigerator at $4{ }^{\circ} \mathrm{C}$ until analysis of main anions and cations. The third was stored at $-18^{\circ} \mathrm{C}$ for $\mathrm{P}$ analysis.

\subsubsection{Bulk sampling deposition in NW Mediterranean (France, Cap Béar: $42^{\circ} 52^{\prime} \mathrm{N} 03^{\circ} 3^{\prime} \mathrm{E}$ )}

Monthly bulk deposition samples $(n=84)$ were collected according to the ADIOS protocol (Markaki et al., 2010) at Cap Béar (Fig. 1) over a seven-year period (2005-2011). The sampling station is situated $20 \mathrm{~km}$ from the town of Perpignan and $158 \mathrm{~m}$ above the sea level. The sampling device used to collect the bulk samples consisted of a $4 \mathrm{~L}$ Nalgene high-density polyethylene bottle, with a polyethylene funnel (surface area $=113 \mathrm{~cm}^{2}$ ) attached to the top; a polyester mesh (mesh $33 \mu \mathrm{m}$ ) at the base of the funnel prevented contamination of the sample by plant debris or insects. Thymol $\left(200 \mathrm{~mL}\right.$ of $2.5 \mathrm{~g} \mathrm{~L}^{-1}$ solution) was added to the sampling bottle to prevent any biological activity (Ayers et al., 1998) during each sampling period, although the acidity of thymol might have influenced the dissolved/particulate equilibrium in the sample. The bottle was wrapped in aluminum foil to avoid direct sun exposure and photochemical degradation of the collected compounds. Whatman filters (nuclepore) with pore diameter of $0.45 \mu \mathrm{m}$ were used for filtration; the filters were rinsed with alcohol in order to avoid residual thymol crystallization on the filter due to poor solubility in water, and then they were weighed. The filtered solutions were stored in the refrigerator $\left(4^{\circ} \mathrm{C}\right)$.

\subsection{Chemical analysis}

\subsubsection{Analysis of $P$ speciation}

The speciation of $\mathrm{P}$ was determined according to the analytical protocol referred to in Standard Methods for the Examination of Water and Wastewater (20th Edition). Total phosphorus (TP) in both dissolved (TDP) and particulate fractions (TPP) was measured after acid digestion of samples according to the persulfate digestion method; TP was measured colorimetrically as $\mathrm{PO}_{4}{ }^{3-}$ at $690 \mathrm{~nm}$ using the stannous chloride method. TP recoveries obtained by the use of certified reference materials (MESS-3) were found to be $98 \pm 12 \%$. Dissolved phosphate (DIP) was determined as $\mathrm{HPO}_{4}{ }^{2-}$ by anion chromatography in samples from the eastern Mediterranean, while in samples from NW Mediterranean it was measured colorimetrically as $\mathrm{PO}_{4}{ }^{3-}$ at $690 \mathrm{~nm}$ using the stannous chloride method (Markaki et al., 2003). Total acid-hydrolyzed inorganic phosphorus was determined after acidification of sample $(\mathrm{pH}=1.6)$ with a mixture of sulfuric acid $(0.05 \mathrm{M})$ and nitric acid $(0.5 \mu \mathrm{M})$, separately in filterable (TIP) and non-filterable (TIP $\left.{ }_{\text {insol }}\right)$ samples. Organically bound phosphates were determined in both soluble (DOP) and insoluble matter $\left(\mathrm{OP}_{\text {insol }}\right)$ by subtracting TIP from TDP and TIP $_{\text {insol }}$ from TPP, respectively, while the condensed phosphates (pyro-, meta-, and other inorganic polyphosphates), hereafter termed $\mathrm{CP}$, were determined only in the soluble fraction by subtracting $\mathrm{HPO}_{4}{ }^{2-}$ from soluble TIP; see the abbreviations in Table S4 in Supplementary material.

The quantification of TDP was achieved by using a calibration curve. For this purpose, the TDP stock solutions were prepared by 


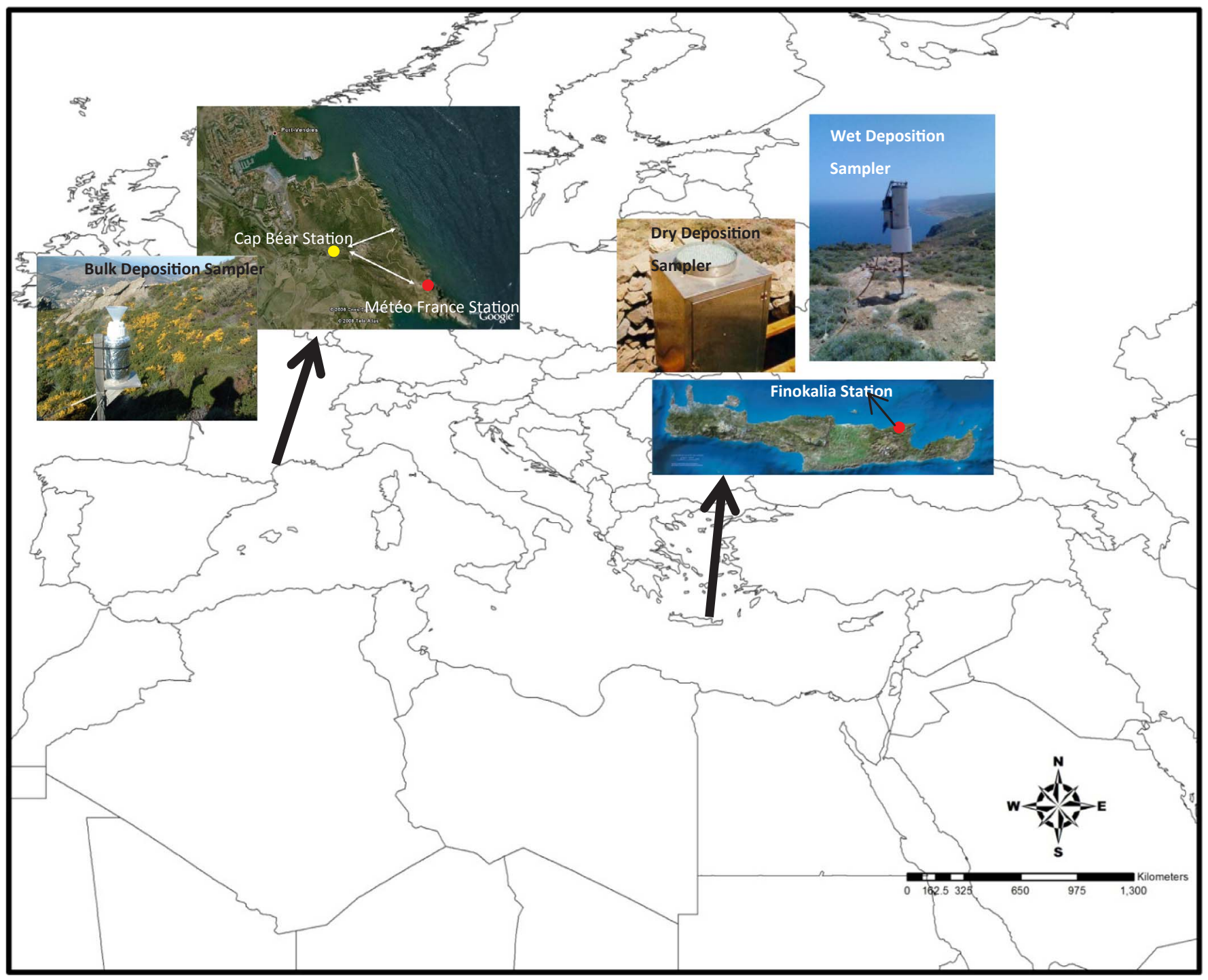

Fig. 1. Finokalia station $\left(35^{\circ} 20^{\prime} \mathrm{N} 25^{\circ} 40^{\prime} \mathrm{E}\right)$ and Cap Béar $\left(42^{\circ} 52^{\prime} \mathrm{N} 03^{\circ} 13^{\prime} \mathrm{E}\right)$.

dissolving equal amounts (in terms of P) of analytical grade $\mathrm{KH}_{2} \mathrm{PO}_{4}$ (Merck \#6537.0500) and adenylic acid (AMP: $\mathrm{C}_{10} \mathrm{H}_{12} \mathrm{~N}_{5} \mathrm{Na}_{2} \mathrm{O}_{7} \mathrm{P}$, Merck\#1.01145.1000). Blank solutions are prepared with Milli-Q water and they were treated as the deposition samples. The detection limit, estimated as three times the standard deviation (SD) of the blank, was found to be $10 \mathrm{ppb} P$ for acid-hydrolyzable and $13 \mathrm{ppb} P$ for TP.

Furthermore, we evaluated our choice to reduce by half the proposed concentration of acid referred to in the protocol of Standard Methods for the Examination of Water and Wastewater (20th Edition) for the determination of total acid-hydrolyzable P (Fig. 2). The main purpose of this test was to assess whether part of the organic $\mathrm{P}$ was recovered as part of the hydrolyzable fraction, by estimating the recoveries of both total inorganic and organic P. In order to achieve this, we used as standards (not a mixture, but separately) sodium pyrophosphate tetrabasic decahydrate $\left(\mathrm{Na}_{2} \mathrm{O}_{7} \mathrm{P}_{2} \cdot 10 \mathrm{H}_{2} \mathrm{O}\right.$, Sigma-Aldrich: 30411$)$ to represent the total hydrolysable $\mathrm{P}$ and adenylic acid to represent the organic $\mathrm{P}$ and then we followed the analytical protocol for the determination of total acid-hydrolyzed inorganic phosphorus as described above. The optimal average recovery of inorganic P $(101 \pm 7 \%)$ in the concentration range of $38-500 \mathrm{ppb}$ was achieved, while the recovery of adenylic acid under the modified acidification was estimated at $22 \pm 4 \%$ in the concentration range of $26-500 \mathrm{ppb}$. This evidence suggests that is possible to remove organic forms of $\mathrm{P}$ in the hydrolyzable fraction, resulting in an underestimation of $\mathrm{OP}$ and

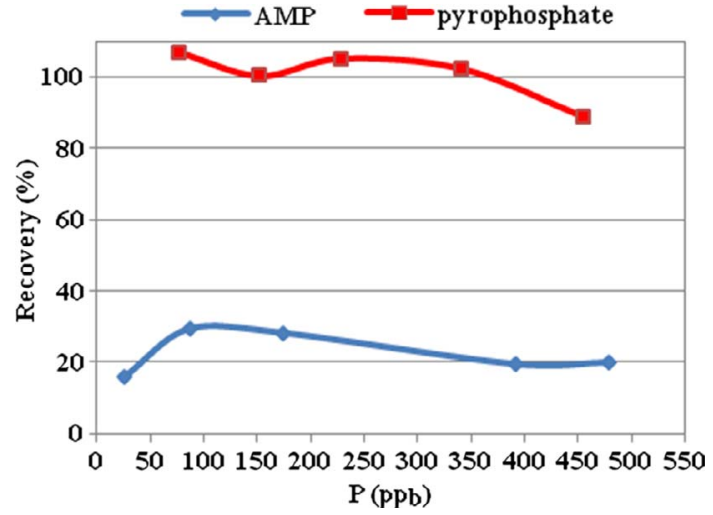

Fig. 2. Recovery of adenylic acid (AMP) and sodium pyrophosphate tetrabasic decahydrate during the acid hydrolysis of a mixture of both forms of $\mathrm{P}$.

overestimation of TIP. The average concentrations of inorganic and organic $\mathrm{P}$ determined during this study were in the range of 26-500 ppb; similar to those achieved in our recovery tests (Fig. 2).

\subsubsection{Analysis of main ions}

The main ions were determined in order for them to be used as 
tracers of various sources. A Dionex AS4A-SC column with ASRS-300 $4 \mathrm{~mm}$ suppressor in auto-suppression mode of operation was used for the analysis of anions $\left(\mathrm{Cl}^{-}, \mathrm{Br}^{-}, \mathrm{NO}_{3}{ }^{-}, \mathrm{SO}_{4}{ }^{2-}, \mathrm{HPO}_{4}{ }^{2-}, \mathrm{C}_{2} \mathrm{O}_{4}{ }^{2-}\right)$ in rain samples and aerosol extractions. All the anions were determined with isocratic elution at $1.5 \mathrm{~mL} \mathrm{~min}{ }^{-1}$ of $\mathrm{Na}_{2} \mathrm{CO}_{3} / \mathrm{NaHCO}_{3}$ eluent. For the cations $\left(\mathrm{Na}^{+}, \mathrm{NH}_{4}{ }^{+}, \mathrm{K}^{+}, \mathrm{Mg}^{2+}\right.$ and $\left.\mathrm{Ca}^{2+}\right)$ a CS12-SC column was used with a CSRS-300 $4 \mathrm{~mm}$ suppressor. Separation was achieved under isocratic conditions with MSA $(20 \mathrm{mM})$ eluent and flow rate of $1.0 \mathrm{~mL} \mathrm{~min}^{-1}$. Details for the IC analysis are reported in Bardouki et al. (2003). The reproducibility of the measurements was better than $2 \%$ and the detection limit ranged from 1 to $5 \mathrm{ppb}$ for the main anions and cations. The detection limit of $\mathrm{HPO}_{4}{ }^{2-}$ was $3 \mathrm{ppb}$, while the average $\mathrm{HPO}_{4}{ }^{2-}$ value of the whole data set was 80 times above the DL. Blanks were always below the detection limits.

\section{Results}

\subsection{Phosphorus speciation in deposition samples over the eastern Mediterranean}

3.1.1. Phosphorus speciation in rain deposition samples during wet season

In Table 1 the $P$ speciation in the rain water samples collected during the wet season (October to March) at Finokalia sampling station for both years (2012 and 2013) is presented. The 2012-2013 average of annual deposited flux of TDP and TPP was estimated at 0.82 and $0.23 \mathrm{mmol} \mathrm{P} \mathrm{m} \mathrm{m}^{-2} \mathrm{y}^{-1}$, respectively. Higher total dissolved phosphorus (TDP) concentrations were recorded in $2012\left(1.02 \mathrm{mmol} \mathrm{P} \mathrm{m}^{-2} \mathrm{y}^{-1}\right)$, while 2013 was characterized by higher total particulate phosphorus (TPP) values. TPP accounted for $11 \%\left(0.13 \mathrm{mmol} \mathrm{P} \mathrm{m}^{-2} \mathrm{y}^{-1}\right)$ and $35 \%$ $\left(0.33 \mathrm{mmol} \mathrm{P} \mathrm{m}^{-2} \mathrm{y}^{-1}\right)$ of total deposited phosphorus (TP) for 2012 and 2013, respectively. The prevalence of SW air masses (Sahara dust outbreaks) during 2013 resulted in higher mass deposition (13.51 $\left.\mathrm{g} \mathrm{m}^{-2}\right)$ compared to $2012\left(7.40 \mathrm{~g} \mathrm{~m}^{-2}\right)$, and may explain this increased level of TPP in 2013.

The significant contribution of organic $\mathrm{P}$ in both soluble and insoluble fractions during both years is characteristic. The average percentage contributions of phosphate ions (DIP), DOP and CP to TDP were found to be 3, 92 and 5\%, and 15, 75 and 10\%, for 2012 and 2013, respectively (Fig. 3). The percentage speciations of TPP for particulate

Table 1

Annual wet and dry deposition of P species during wet and dry season, respectively over the Eastern Mediterranean.

\begin{tabular}{|c|c|c|c|c|}
\hline & \multicolumn{4}{|c|}{ Deposition ( $\mathrm{mmol} \mathrm{m}^{-2}$ year $^{-1}$ ) } \\
\hline & \multicolumn{2}{|c|}{ Rain season } & \multicolumn{2}{|c|}{ Dry season } \\
\hline & 2012 & 2013 & 2012 & 2013 \\
\hline \multicolumn{5}{|l|}{ Soluble } \\
\hline $\mathrm{h}(\mathrm{cm})$ & 34.6 & 32.1 & & \\
\hline TDP & 1.02 & 0.61 & 0.58 & 0.80 \\
\hline DOP & 0.94 & 0.46 & 0.36 & 0.55 \\
\hline $\mathrm{CP}$ & 0.05 & 0.06 & 0.09 & 0.22 \\
\hline $\mathrm{PO}_{4}{ }^{3-}$ & 0.03 & 0.09 & 0.13 & 0.03 \\
\hline $\mathrm{nss}-\mathrm{Ca}^{2+}$ & 9.73 & 16.27 & 18.44 & 28.50 \\
\hline nss-Sulfate & 4.68 & 6.25 & 10.68 & 11.80 \\
\hline \multicolumn{5}{|l|}{ Insoluble } \\
\hline TPP & 0.13 & 0.33 & 0.24 & 0.44 \\
\hline $\mathrm{OP}_{\text {insol }}$ & 0.06 & 0.21 & 0.11 & 0.25 \\
\hline TIP $_{\text {insol }}$ & 0.07 & 0.12 & 0.13 & 0.19 \\
\hline Particulate mass ${ }^{\mathrm{a}}$ & 4.37 & 6.10 & 3.03 & 7.48 \\
\hline \multicolumn{5}{|l|}{ Total P } \\
\hline OPtotal & 1.00 & 0.67 & 0.47 & 0.80 \\
\hline TIPtotal & 0.15 & 0.27 & 0.35 & 0.44 \\
\hline $\mathrm{TP}$ & 1.15 & 0.94 & 0.82 & 1.23 \\
\hline
\end{tabular}

${ }^{\text {a }}$ Bulk mass deposition in $\mathrm{g} \mathrm{m}^{-2}$ year $^{-1}$. inorganic $\mathrm{P}\left(\mathrm{TIP}_{\text {insol }}\right)$ and particulate organic $\mathrm{P}\left(\mathrm{OP}_{\text {insol }}\right)$, was found to be 54 and $46 \%$, and 36 and $64 \%$, for 2012 and 2013, respectively.

In terms of percentage contribution, wet deposition can contribute equally to the dry (see ection 3.1 .2 ), since $\sim 50 \%$ of TP (Table 1 ; twoyear average) is deposited during the rainy season. This observation is in agreement with similar studies performed in other sites across the Mediterranean Sea (Markaki et al., 2010). Monthly wet fluxes of TDP and TPP during the wet season 2012-13 with rain height and wet-deposited atmospheric particulate mass are depicted in Fig. 4. During wet seasons TDP and TPP follow well the particulate mass variability and rain height, especially in 2012.

A Spearman's correlation analysis was run in rain samples ( $\mathrm{n}=40$ ), using concentration values ( $\mathrm{ppb}$ ) between the $\mathrm{P}$ species and various parameters including major ions and particulate mass (Table S1). Considering as significant the correlations with $\mathrm{p}<0.05$, information regarding the sources of $\mathrm{P}$ species could be retrieved. Insoluble inorganic phosphorus species were related both to particulate mass $\left(r_{s}=0.41, p<0.05\right)$ and to nss- $\mathrm{Ca}^{2+}\left(\mathrm{r}_{\mathrm{s}}=0.39, \mathrm{p}<0.05\right)$ suggesting a contribution from dust. Furthermore, insoluble organic $\mathrm{P}$ species correlated significantly to oxalate, indicating a contribution from regional pollution and photochemistry $\left(r_{s}=0.60\right.$, $\mathrm{p}<0.00005)$. Oxalate is produced secondary by the oxidation of volatile biogenic organic compounds by $\mathrm{OH}$ and $\mathrm{NO}_{3}$ radicals $(79 \%$ of the global oxalate budget), while more than $60 \%$ of oxalate is removed from the atmosphere by wet deposition (Myriokefalitakis et al., 2011). Furthermore, it was also correlated with $n s s-\mathrm{K}^{+} \quad\left(\mathrm{r}_{\mathrm{s}}=0.59\right.$, $\mathrm{p}<0.0005$ ) indicating contribution from wood burning or soil. Finally, DOP correlated well with nss- $\mathrm{Ca}^{2+}\left(\mathrm{r}_{\mathrm{s}}=0.46, \mathrm{p}<0.005\right)$ suggesting a contribution from dust.

\subsubsection{P speciation in dry deposition samples during dry season}

Dry deposition samples $(n=29)$ were collected on a two-week basis during the dry season (April to September). Similar to the rainy season, an important contribution of organic $\mathrm{P}$ in both soluble and insoluble fractions was observed during both years (Fig. 5). Indeed, the two-year average percentage contributions of dissolved $\mathrm{P}$ fractions (DIP, DOP and CP) to TDP during the dry period were found to be $11 \%$ $\left(0.08 \mathrm{mmol} \mathrm{P} \mathrm{m}^{-2}\right), \quad 66 \% \quad\left(0.46 \mathrm{mmol} \mathrm{P} \mathrm{m}^{-2}\right) \quad$ and $23 \%$ $\left(0.16 \mathrm{mmol} \mathrm{P} \mathrm{m}^{-2}\right)$, respectively highlighting the importance of organic $\mathrm{P}$ forms in the dissolved fraction. On the other hand, the average percentage speciation of TPP was $49 \%$ and $51 \%$ for particulate inorganic $\mathrm{P}\left(\mathrm{TIP}_{\text {insol }}\right)$ and particulate organic $\mathrm{P}\left(\mathrm{OP}_{\text {insol }}\right)$, respectively, indicating an equal contribution of inorganic and organic forms in the particulate fraction.

A Spearman's correlation analysis was run also in dry deposition samples data set $(\mathrm{n}=29)$ using concentration values $(\mathrm{ppb})$, and the results are presented in Table S2. TIP insol appears to be associated with more complex matrixes since significant correlations were found with different tracers. Furthermore, TIP $_{\text {insol }}$ was significantly correlated with nss-SO ${ }_{4}^{2-} \quad\left(r_{\mathrm{s}}=0.47, \quad \mathrm{p}<0.05\right)$ and $\mathrm{NH}_{4}{ }^{+} \quad\left(\mathrm{r}_{\mathrm{s}}=0.64\right.$, $\mathrm{p}<0.0005$ ), suggesting a possible contribution from anthropogenic and agricultural activities, such as fertilizers. TIP $_{\text {insol }}$ was also correlated with nss- $\mathrm{K}^{+}\left(\mathrm{r}_{\mathrm{s}}=0.43, \mathrm{p}<0.05\right)$ suggesting a possible contribution from wood burning or soil, while marine sources are not excluded, since significant correlation was found with $\mathrm{Cl}^{-}\left(\mathrm{r}_{\mathrm{s}}=0.39\right.$, $\mathrm{p}<0.05)$.

Insoluble organic $\mathrm{P}$ species were correlated well with $\mathrm{nss}-\mathrm{K}^{+}$ $\left(\mathrm{r}_{\mathrm{s}}=0.39, \mathrm{p}<0.05\right)$ suggesting a possible contribution from wood burning or soil. Significant correlation was observed between DIP and $\mathrm{NH}_{4}{ }^{+}\left(\mathrm{r}_{\mathrm{s}}=0.41, \mathrm{p}<0.05\right)$ indicating contribution from agriculture. Finally, CP was correlated well with the presence of the particulate mass $\left(\mathrm{r}_{\mathrm{s}}=0.49, \mathrm{p}<0.05\right)$. 
a)

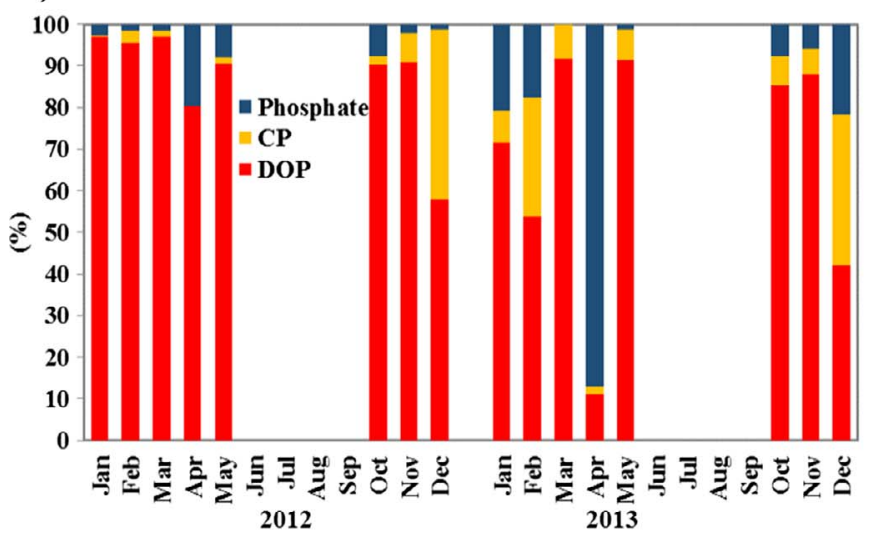

b)

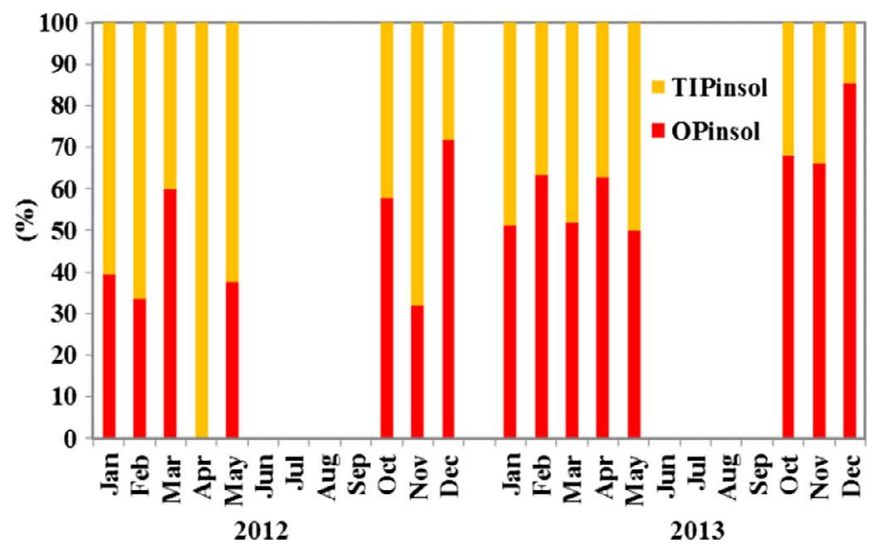

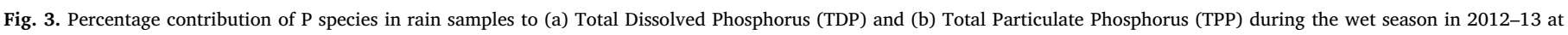
Finokalia sampling station.

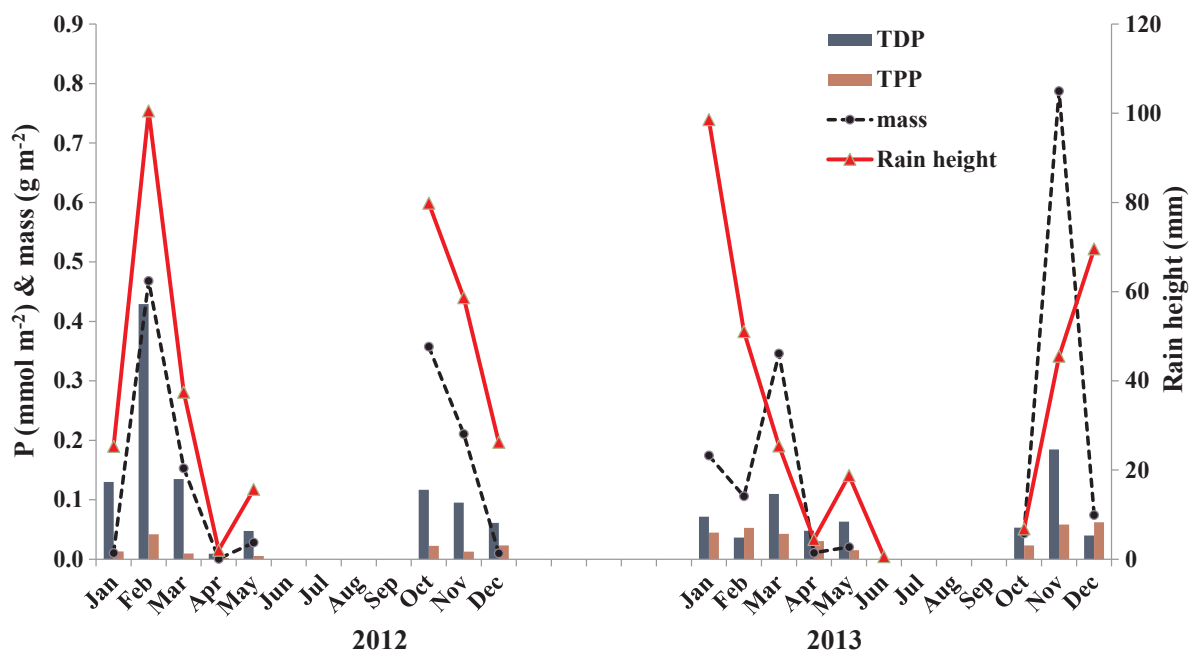

Fig. 4. Monthly wet fluxes of TDP \& TPP during wet season 2012-13 in Finokalia sampling station versus rain height and wet deposited atmospheric particulate mass.

\subsection{Phosphorus speciation in bulk deposition samples over NW Mediterranean}

In this study speciation analysis for $\mathrm{P}$ was only performed in the filterable part of bulk deposition samples (TDP) collected at the Cap Béar sampling station. In the seven years 2005-2011, the average of annual bulk deposited flux of TDP was estimated at

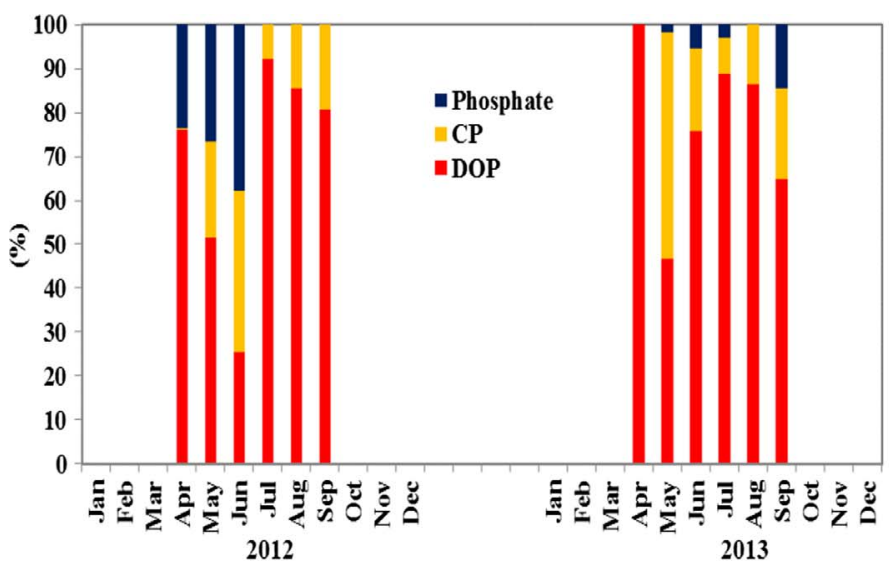

$2.16 \pm 0.56 \mathrm{mmol} \mathrm{P} \mathrm{m}{ }^{-2} \mathrm{y}^{-1}$. Annual fluxes were calculated from the monthly data by integration and extrapolated to 12 months in case of missing data. The average percentage contribution of the various $\mathrm{P}$ species to TDP was $44 \%$ for DOP $\left(0.94 \pm 0.44 \mathrm{mmol} \mathrm{P} \mathrm{m}^{-2} \mathrm{y}^{-1}\right)$, $34 \%$ for $\mathrm{CP}\left(0.74 \pm 0.69 \mathrm{mmol} \mathrm{P} \mathrm{m}^{-2} \mathrm{y}^{-1}\right)$ and $22 \%$ for DIP $\left(0.48 \pm 0.35 \mathrm{mmol} \mathrm{P} \mathrm{m}^{-2} \mathrm{y}^{-1}\right)$.

A Spearman's correlation analysis was run in bulk deposition

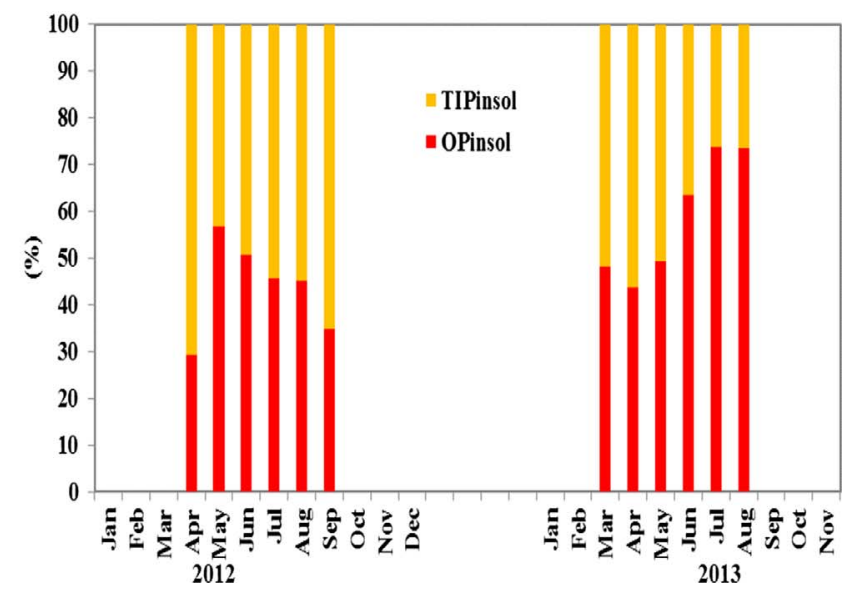

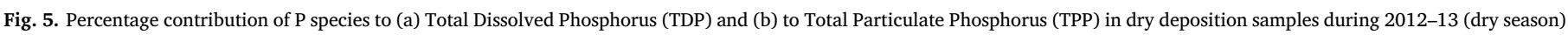
in Finokalia sampling station. 


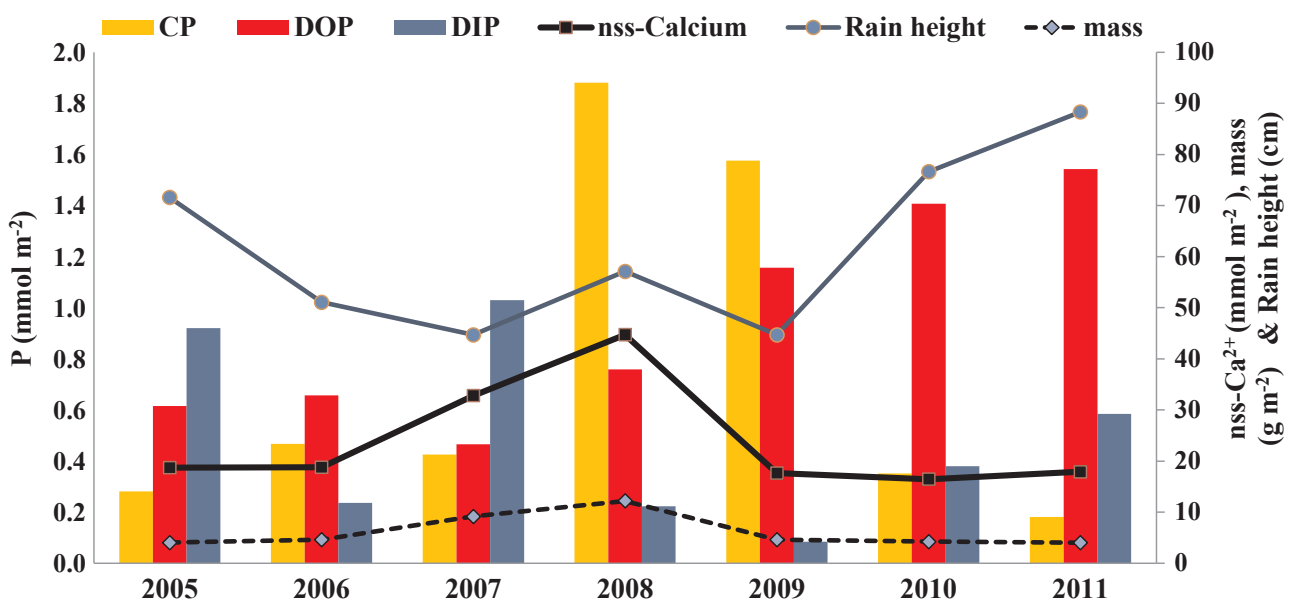

Fig. 6. Inter-annual bulk deposition of $\mathrm{P}$ species in parallel with nss- $\mathrm{Ca}^{2+}$, particulate mass \& rain height $(\mathrm{cm})$ for seven years (2005-2011) in NW Mediterranean (Cap Béar).

samples data set $(\mathrm{n}=70)$ using concentration values, and the results are presented in Table S3. DIP correlated with nss-Ca ${ }^{2+}\left(r_{s}=0.34\right.$, $\mathrm{p}<0.005)$ and $\mathrm{NO}_{3}{ }^{-}\left(\mathrm{r}_{\mathrm{s}}=0.28, \mathrm{p}<0.05\right)$ suggesting contribution from a mixture of dust and anthropogenic sources. No significant correlation was found between both DOP and CP with the main ions, confirming the complex matrix of those P species over the NW Mediterranean.

The inter-annual variability of bulk deposition $\mathrm{P}$ species in parallel with particulate mass, $\mathrm{nss}^{-\mathrm{Ca}^{2+}}$ and rainfall during the seven-year period (2005-2011) is depicted in Fig. 6 and Table 3. Maximum values of nss- $\mathrm{Ca}^{2+}$ were recorded in $2007\left(32.8 \mathrm{mmol} \mathrm{m}^{-2} \mathrm{y}^{-1}\right)$ and 2008 (44.7 $\mathrm{mmol} \mathrm{m}^{-2} \mathrm{y}^{-1}$ ), but only during 2007 was followed by the maximum of DIP (1.03 mmol P m $\mathrm{m}^{-2} \mathrm{y}^{-1}$ ). Pey et al. (2013) studied the occurrence of African dust outbreaks over different areas of the Mediterranean Basin over an 11-year period (2001-2011). According to that study the highest number of dust event days over the NW Mediterranean were recorded in 2007, which is in agreement with the high deposition flux of nss- $\mathrm{Ca}^{2+}$ reported in this study for that year. Maximum DOP was observed during 2011 (1.55 $\left.\mathrm{mmol} \mathrm{P} \mathrm{m}^{-2} \mathrm{y}^{-1}\right)$, parallel with the maximum rainfall.

The seven years of data were divided in two periods, depending on the occurrence of rain: the dry period (from June to August) with total average monthly rainfall less than $2.2 \mathrm{~cm}$ and the wet period (from September to May). The main deposition mechanism of P species in the NW Mediterranean is wet deposition, with about $80 \%$ of the TDP deposited during the wet period, in agreement with Markaki et al. (2010). Monthly average percentage speciation of $\mathrm{P}$ species to TDP is depicted in Fig. 7; with rain height, nss- $\mathrm{SO}_{4}{ }^{2-}$, and $\mathrm{nss}^{-\mathrm{Ca}^{2+}}$ as monthly averages through the years. In the dry season, the maximum percentage contribution of DOP $\left(0.10 \mathrm{mmol} \mathrm{m}^{-2}\right)$ was reported in August, while for inorganic species in June and July. During the wet season, the two rainfall maxima occurred in May and October and followed the maximum monthly fluxes of nss-Ca ${ }^{2+}$ (5.87 and $2.52 \mathrm{mmol} \mathrm{m}^{-2}$, respectively). The maximum percentage contribution of DOP (59\%) was reported for October while in May there was a prevalence of inorganic P.

\section{Discussion}

It is well known that straightforward comparisons within and between regions are difficult because of differences in the sample types, sampling period lengths, and sample handling procedures. For instance, bulk collectors, used in Cap Béar, could underestimate dry deposition collection (Ridame et al., 1999). However, the efficiency of this sampler was evaluated by comparing it with the glass bead collectors used in Finokalia sampling station, in Markaki et al. (2010), and it was found that both sampling devices collected dry deposition of $\mathrm{P}$ effectively. Table 2 depicts the literature data regarding the $\mathrm{P}$ speciation of deposition samples around Mediterranean areas. TPP fluxes measured in this study for the E. Mediterranean are in agreement with the values reported by Izquierdo et al. (2012) for NE Spain, not only when yearly averaged values were compared, but also during wet and dry periods (Table 2). Phosphate estimated during this study for the E. Mediterranean was within the range of the values reported by Markaki et al. (2003, 2010). In addition, DIP fluxes calculated here for Cap Béar

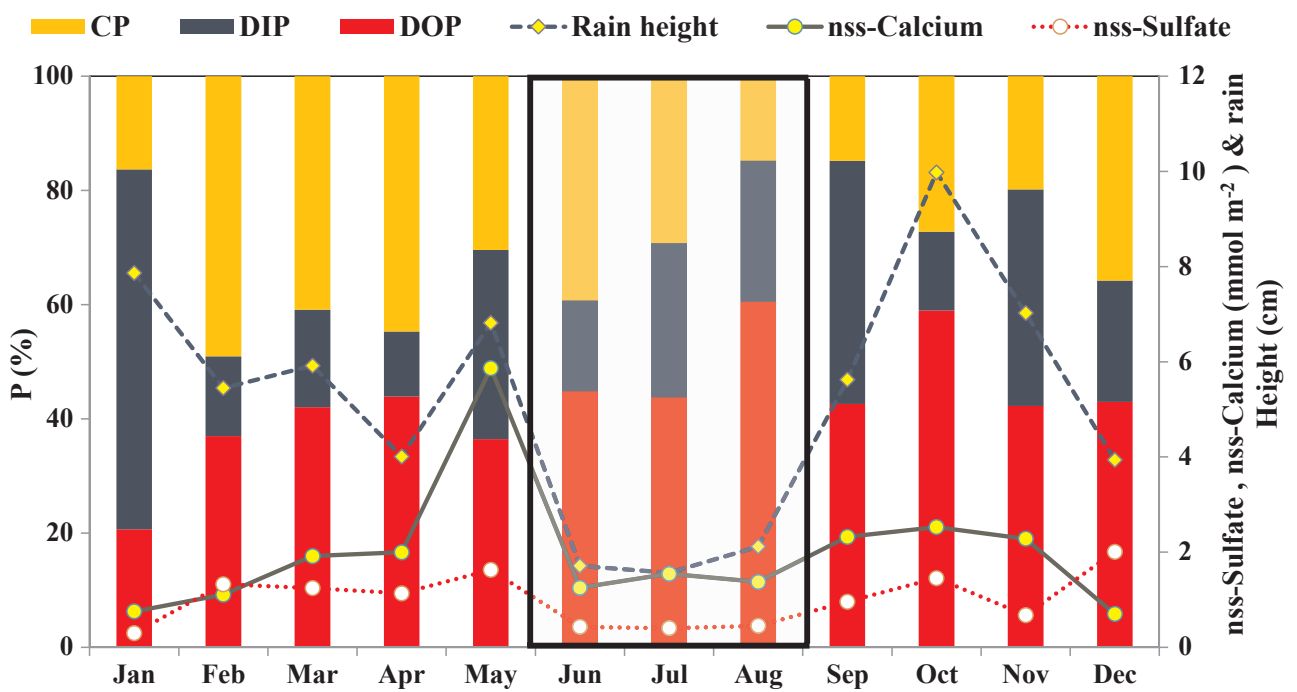

Fig. 7. Monthly average percentage contribution of P species to Total Dissolved Phosphorus (TDP) in bulk deposition samples during 2005-2011 in Cap Béar, with rain height, nss- $-\mathrm{SO}_{4}{ }^{2-}$, \& nss- $\mathrm{Ca}^{2+}$ as monthly average through the years. The frame corresponds to dry season. 
Table 2

Annual deposition (wet \& dry) of P species in around Mediterranean areas in $\mathrm{mmol} \mathrm{m}^{-2}$ year ${ }^{-1}$.

\begin{tabular}{|c|c|c|c|c|c|}
\hline & Wet & Dry & Total & Period & Reference \\
\hline \multicolumn{6}{|l|}{$T P$} \\
\hline CapoCavallo (Corsica) & & & 1.29 & $1986-87$ & Bergametti et al. (1992) \\
\hline CapFerrat, France & 0.16 & - & & 1997-98 & Migon and Sandroni (1999) \\
\hline Sierra Nevada, Spain & 0.18 & 0.45 & 0.64 & 2001 & Moral-Baquero et al. (2006) \\
\hline All Medit. Sites & & & 1.06 & 2001-02 & Guieu et al. (2010) \\
\hline Crete & 1.15 & 0.82 & 1.97 & 2012 & This study \\
\hline Crete & 0.94 & 1.23 & 2.17 & 2013 & This study \\
\hline \multicolumn{6}{|l|}{$T P P$} \\
\hline Cap Ferrat, France & 0.07 & - & & & Migon and Sandroni (1999) \\
\hline Montseny (NE Spain) & 0.29 & 0.29 & 0.58 & $2002-03$ & Izquierdo et al. (2012) \\
\hline Crete & 0.13 & $0.24^{\mathrm{a}}$ & $0.37^{\mathrm{a}}$ & 2012 & This study \\
\hline Crete & 0.33 & $0.44^{\mathrm{a}}$ & $0.77^{\mathrm{a}}$ & 2013 & This study \\
\hline \multicolumn{6}{|l|}{$T D P$} \\
\hline Cap Ferrat, France & 0.10 & - & & 1997-98 & Migon and Sandroni (1999) \\
\hline Frioul Island & & & 0.39 & 2015-16 & Djaoudi et al. (this issue) \\
\hline Crete & 1.02 & $0.58^{\mathrm{a}}$ & 1.60 & 2012 & This study \\
\hline Crete & 0.61 & $0.80^{\mathrm{a}}$ & 1.41 & 2013 & This study \\
\hline Cap Béar & & & 2.16 & 2005-11 & This study \\
\hline \multicolumn{6}{|l|}{$T I P_{\text {total }}$} \\
\hline Israel & 0.29 & 1 & 1.29 & 1995-98 & Herut et al. (2002) \\
\hline Crete & 0.15 & $0.35^{\mathrm{a}}$ & 0.50 & 2012 & This study \\
\hline Crete & 0.27 & $0.44^{\mathrm{a}}$ & 0.71 & 2013 & This study \\
\hline Cap Béar & & & 1.22 & 2005-11 & This study \\
\hline \multicolumn{6}{|l|}{$D O P$} \\
\hline Frioul Island & & & 0.07 & 2015-16 & Djaoudi et al. (this issue) \\
\hline Crete & 0.94 & $0.36^{\mathrm{a}}$ & 1.30 & 2012 & This study \\
\hline Crete & 0.46 & $0.55^{\mathrm{a}}$ & 1.01 & 2013 & This study \\
\hline Cap Béar & & & 0.94 & 2005-2011 & This study \\
\hline \multicolumn{6}{|l|}{ DIP or $\mathrm{PO}_{4}^{3-}$} \\
\hline Cap Ferrat, France & 0.06 & & & & Migon and Sandroni (1999) \\
\hline Cap Ferrat, France & 0.15 & 0.76 & & 2010 & Pasqueron de Fommervault et al. (2015) \\
\hline Cap Ferrat, France & 0.10 & 0.40 & & 2011 & Pasqueron de Fommervault et al. (2015) \\
\hline Cap Ferrat, France & 0.09 & 0.75 & & 2013 & Pasqueron de Fommervault et al. (2015) \\
\hline Crete & 0.07 & 0.13 & 0.19 & $1999-2000$ & Markaki et al. (2003) \\
\hline Erdemli (Turkey) & - & 0.17 & & 1999 & Markaki et al. (2003) \\
\hline Erdemli (Turkey) & 0.31 & - & & $1996-1997$ & Özsoy (2003) \\
\hline Cap Béar & & & 0.57 & 2001-2002 & Markaki et al. (2010) \\
\hline Cap Béar & & & 0.67 & $2002-2003$ & Markaki et al. (2010) \\
\hline Ostriconi & & & 0.46 & 2001-2002 & Markaki et al. (2010) \\
\hline Ostriconi & & & 0.43 & $2002-2003$ & Markaki et al. (2010) \\
\hline Crete & & & 0.25 & 2001-2002 & Markaki et al. (2010) \\
\hline Crete & & & 0.33 & $2002-2003$ & Markaki et al. (2010) \\
\hline Montseny (NE Spain) & $0.05-0.06$ & $0.06-0.08$ & & $2002-03$ & Izquierdo et al. (2012) \\
\hline Crete & 0.03 & $0.13^{\mathrm{a}}$ & 0.16 & 2012 & This study \\
\hline Crete & 0.09 & $0.03^{\mathrm{a}}$ & 0.12 & 2013 & This study \\
\hline Cap Béar & & & 0.48 & $2005-2011$ & This study \\
\hline
\end{tabular}

${ }^{\text {a }}$ The fluxes are referred to dry period (April-September) in Crete.

$\left(0.48 \pm 0.35 \mathrm{mmol} \mathrm{m}^{-2} \mathrm{y}^{-1}\right)$ are in agreement with the previous study performed in this area (Markaki et al., 2010) and are higher compared to the eastern basin.

Both wet and dry deposition fluxes make significant contributions to the atmospheric phosphorus flux over the E. Mediterranean, although their relative contributions vary depending on precipitation rates and the presence of mineral dust. Generally, soluble P, especially the organic species, are dominant during the wet season, contributing up to $89 \%$ and $65 \%$ of the total dissolved P for 2012 and 2013, respectively. Higher TPP/TP ratios are recorded during the dry season, which seems to be linked to dust outbreaks, since they follow well the variation of nss-Ca ${ }^{2+}$ fluxes (Table 1 ). This was also observed by Baker et al. (2006), who predict lower solubility of P in samples of Saharan origin. In addition, results from P-NEXFS spectroscopy (Longo et al., 2014) suggest that the inorganic $\mathrm{P}$ is mainly apatite and metal-P, confirming further that Saharan outbreaks enrich the E. Mediterranean with insoluble inorganic $\mathrm{P}$.

The inter-annual variability in deposited particulate mass during the dry season (Table 1) results in an increase of the particulate mass flux during 2013 by 146\% followed by increases of $50 \%$ in TP and $70 \%$ in total organic phosphorus compared to the dry season in 2012. It is difficult to attribute this increase exclusively to anthropogenic sources or dust events, since the two-week resolution time of sampling makes it impossible to categorize the samples into wind sectors. However, Mahowald et al. (2008), in their global atmospheric P assessment, concluded that the largest source by far of atmospheric phosphorus is mineral dust from the wind erosion of soils, and suggested that this source accounts for $82 \%$ of the global aerosol P.

In contrast to the eastern Mediterranean, wet deposition makes a significant contribution to the atmospheric phosphorus flux over the NW Mediterranean, with about $80 \%$ of the TDP being deposited with rain. The seven-year average of TDP during the wet season (1.78 $\pm 0.44 \mathrm{mmol} \mathrm{m}^{-2} \mathrm{y}^{-1}$; Table 3) was almost double compared to the two-year average TDP during the wet season in the eastern Mediterranean $\left(0.82 \mathrm{mmol} \mathrm{m}^{-2} \mathrm{y}^{-1}\right.$; Table 1$)$. The difference is attributed mainly to the precipitation level being 2-3 times higher in the NW Mediterranean compared to the Eastern. However, DOP is the dominant $\mathrm{P}$ fraction at both sites and presents similar fluxes $(0.74$ and 
Table 3

Inter annual variability of bulk deposition of $\mathrm{P}$ species during wet and dry season in Cap Béar in $\mathrm{mmol} \mathrm{m}^{-2}$ year $^{-1}$.

\begin{tabular}{|c|c|c|c|c|c|c|c|c|c|c|c|c|c|c|c|c|c|}
\hline & \multicolumn{2}{|l|}{2005} & \multicolumn{2}{|l|}{2006} & \multicolumn{2}{|l|}{2007} & \multicolumn{2}{|l|}{2008} & \multicolumn{2}{|l|}{2009} & \multicolumn{2}{|l|}{2010} & \multicolumn{2}{|l|}{2011} & \multicolumn{3}{|l|}{ Average } \\
\hline & Wet & Dry & Wet & Dry & Wet & Dry & Wet & Dry & Wet & Dry & Wet & Dry & Wet & Dry & Wet & Dry & Total \\
\hline $\mathrm{H}(\mathrm{cm})$ & 67.7 & 3.9 & 47.7 & 3.4 & 40.9 & 3.8 & 49.6 & 7.5 & 39.4 & 5.3 & 71.6 & 5.0 & 79.6 & 8.8 & & & \\
\hline TDP & 1.53 & 0.28 & 1.12 & 0.24 & 1.70 & 0.22 & 2.45 & 0.41 & 2.16 & 0.66 & 1.56 & 0.58 & 1.94 & 0.37 & $1.78 \pm 0.44$ & $0.39 \pm 0.17$ & $2.16 \pm 0.56$ \\
\hline DOP & 0.58 & 0.04 & 0.53 & 0.12 & 0.44 & 0.02 & 0.60 & 0.15 & 0.71 & 0.44 & 0.95 & 0.46 & 1.36 & 0.19 & $0.74 \pm 0.32$ & $0.20 \pm 0.18$ & $0.94 \pm 0.44$ \\
\hline $\mathrm{CP}$ & 0.17 & 0.11 & 0.40 & 0.06 & 0.34 & 0.09 & 1.64 & 0.25 & 1.36 & 0.22 & 0.34 & 0.02 & 0.18 & 0.00 & $0.63 \pm 0.60$ & $0.11 \pm 0.09$ & $0.74 \pm 0.69$ \\
\hline $\mathrm{PO}_{4}{ }^{3-}$ & 0.78 & 0.14 & 0.18 & 0.05 & 0.92 & 0.11 & 0.21 & 0.01 & 0.08 & 0.00 & 0.27 & 0.11 & 0.40 & 0.18 & $0.41 \pm 0.32$ & $0.09 \pm 0.07$ & $0.48 \pm 0.35$ \\
\hline
\end{tabular}

$0.70 \mathrm{mmol} \mathrm{m} \mathrm{y}^{-1}$, respectively), despite the difference in precipitation level, indicating more intensive sources of organic P species in the eastern basin. During dry season, the seven-year average of TDP in the NW Mediterranean ( $0.39 \pm 0.17 \mathrm{mmol} \mathrm{m}^{-2} \mathrm{y}^{-1}$; Table 3$)$ was almost a half of that in the eastern basin $\left(0.69 \mathrm{mmol} \mathrm{m}^{-2} \mathrm{y}^{-1}\right.$; Table 1$)$, mainly because of the extended dry period at the Levantine basin. Dissolved organic P species are dominant at both sites, with fluxes of $0.20 \mathrm{mmol} \mathrm{m}^{-2} \mathrm{y}^{-1}$ and $0.46 \mathrm{mmol} \mathrm{m}^{-2} \mathrm{y}^{-1}$, for the NW and $\mathrm{E}$. Mediterranean, respectively.

The atmospheric deposition of $\mathrm{P}$ may influence the primary productivity (PP) of the euphotic zone in Mediterranean seawater, especially during the stratification period, which experiences a severe phosphate depletion after the spring bloom, leading to a P-limitation of biological activity (Krom et al., 1991; Thingstad et al., 1998). It is well known that phosphate is the most soluble form of inorganic phosphorus that can be consumed by organisms and converted to organic or other inorganic forms of P (Björkman and Karl, 1994). The different organic phosphorus compounds are potential sources of phosphorus for marine communities, since marine biota could hydrolyze them to orthophosphate (Björkman and Karl, 1994). However, the fraction of atmospheric phosphorus that is bioavailable is uncertain at present (Vet et al., 2014).

In order to calculate the maximum impact of total phosphorus deposition in the marine ecosystems, we assumed that all TDP is bioavailable. However, the bioavailability of soluble organic phosphorus remains unknown, while non-phosphate inorganic phosphorus could be bioavailable due to atmospheric acidity (Nenes et al., 2011; Krom et al., 2016; Stockdale et al., 2016). The average total deposition (wet + dry) of $\mathrm{P}$ during 2012 and 2013 was estimated at $1.51 \mathrm{mmol} \mathrm{P} \mathrm{m}^{-2} \mathrm{y}^{-1}$ in the eastern Mediterranean. However, this value is an underestimate, since dry deposition referred to during the dry season only, and not to the entire year. Converting the TDP flux into carbon uptake by using the Redfield C/P ratio of 106, the TDP is found to be responsible, on an annual basis, for the fixation of $1.92 \mathrm{~g} \mathrm{C} \mathrm{m}^{-2} \mathrm{y}^{-1}$. The annual new productivity for the eastern Mediterranean was estimated in previous studies to be $5 \mathrm{~g} \mathrm{C} \mathrm{m}^{-2} \mathrm{y}^{-1}$ (Kress and Herut, 2001), which means that the atmospheric deposition of TDP contributes $38 \%$ to new production. In the NW Mediterranean, the seven-year average (2005-11) of TDP was estimated at $2.16 \mathrm{mmol} \mathrm{P} \mathrm{m}^{-2} \mathrm{y}^{-1}$ (Table 3), and is responsible for the fixation of $2.75 \mathrm{~g} \mathrm{C} \mathrm{m}^{-2} \mathrm{y}^{-1}$. The mean value of new production in the area during 1993-1999 was estimated at $42 \mathrm{~g} \mathrm{C} \mathrm{m}^{-2} \mathrm{y}^{-1}$ (Marty and Chiavérini, 2002), which means that the atmospheric input of TDP represents only about $7 \%$ of new production. However, in less productive periods in the NW Mediterranean, new production is about $19 \mathrm{~g} \mathrm{C} \mathrm{m}^{-2} \mathrm{y}^{-1}$ (Marty and Chiavérini, 2002). In this case, the atmospheric TDP input of $2.75 \mathrm{~g} \mathrm{C} \mathrm{m}^{-2} \mathrm{y}^{-1}$ represents $14 \%$ of the new production.

\section{Conclusions}

It is now well recognized that organic $\mathrm{P}$ is not only a missing piece of atmospheric P but is also an important contributor to atmospheric deposition of P. During this study, wet and dry deposition samples from the eastern and NW Mediterranean were analyzed for P speciation. The wet deposition of TDP in the NW Mediterranean was almost double the two-year average of TDP during the wet season in the eastern Mediterranean, mainly due to the 2-3 times higher precipitation rate in the northwestern basin. However, it is important to stress that DOP is the dominant P fraction at both sites. Dry deposition of TDP in the NW Mediterranean is less than half of that in the Eastern basin, mainly because of the extended dry period in the Levantine basin. Similarly, to the wet deposition, the soluble organic $\mathrm{P}$ species in dry deposition are dominant in both sites, accounting for at least $50 \%$ of the TDP.

Although additional work is needed to evaluate P bioavailability, especially regarding the organic fraction, this study clearly shows that the atmospheric deposition of TDP could contribute up to 38\% of new production in the eastern Mediterranean, while in oligotrophic zones of the NW Mediterranean, the atmospheric TDP input could represent up to $14 \%$ of the new production.

\section{Acknowledgments}

The research project was financed by the EU project Perseus (FP7) and was conducted as part of the WP4 MERMEX/MISTRALS project and is a contribution to the international SOLAS, IMBER and LOICZ program. KV acknowledges the financial support of PHOSPHOTRAC (Proposal Number: 707624).

\section{References}

Altieri, K.E., Turpin, B.J., Seitzinger, S.P., 2009. Oligomers, organosulfates, and nitrooxy organosulfates in rainwater identified by ultra-high resolution electrospray ionization FT-ICR mass spectrometry. Atmos. Chem. Phys. 9, 2533-2542.

Pierre, Amato, Parazols, Marius, Sancelme, Martine, Mailhot, Gilles, Laj, Paolo, Delort, An-Marie, 2007. An important oceanic source of micro-organisms for cloud water at the Puy de Dôme (France). Atmos. Environ. 41, 8253-8263.

Ayers, G.P., Fukuzaki, N., Gillett, R.W., Selleck, P.W., Powell, J.C., Hara, H., 1998. Thymol as a biocide in Japanese rainwater. J. Atmos. Chem. 30, 301-310.

Baker, A.R., Jickells, T.D., Witt, M., Linge, K.L., 2006. Trends in the solubility of iron, aluminium, manganese and phosphorus in aerosol collected over the Atlantic Ocean. Mar. Chem. 98 (1), 43-58.

Bardouki, H., Berresheim, H., Vrekoussis, M., Sciare, J., Kouvarakis, G., Oikonomou, K. Schneider, Jodi, Mihalopoulos, N., 2003. Gaseous (DMS, MSA, $\mathrm{SO}_{2}, \mathrm{H}_{2} \mathrm{SO}_{4}$ and DMSO) and particulate (sulfate and methanesulfonate) sulfur species over the northeastern coast of Crete. Atmos. Chem. Phys. Eur. Geosci. Union 3 (5), 1871-1886.

Bergametti, G.E., Remoudaki, E., Losno, R., Steiner, E., Chatenet, B., Buat-Menard, P., 1992. Source, transport and deposition of atmospheric phosphorus over the northwestern Mediterranean. J. Atmos. Chem. 14, 501-513.

Björkman, Karin, Karl, David M., 1994. Bioavailability of inorganic and organic phosphorus compounds to natural assemblages of microorganisms in Hawaiian coastal waters. Mar. Ecol. Prog. Ser. 111, 265-273.

Castro-Jiménez, J., Berrojalbiz, N., Pizarro, M., Dachs, J., 2014. Organophosphate ester (OPE) flame retardants and plasticizers in the open Mediterranean and Black Seas Atmosphere. Environ. Sci. Technol. 48, 3203-3209.

Castro-Jiménez, J., González-Gaya, Belén, Pizarro, Mariana, Casal, Paulo, PizarroAlvarez, Cristina, Dachs, Jordi, 2016. Organophosphate ester flame retardants and plasticizers in the global oceanic atmosphere. Environ. Sci. Technol. 50 (23), 
$12831-12839$.

Coscollà, Clara, Castillo, Mercedes, Pastor, Agustin, Yusà, Vicent, 2011. Determination of 40 currently used pesticides in airborne particulate matter $\left(\mathrm{PM}_{10}\right)$ by microwaveassisted extraction and gas chromatography coupled to triple quadrupole mass spectrometry. Anal. Chim. Acta 693 (2011), 72-81.

Degrendele, C., Okonski, K., Melymuk, L., Landlová, L., Kukučka, P., Audy, O., Kohoutek, J., Čupr, P., Klánová, J., 2016. Pesticides in the atmosphere: a comparison of gasparticle partitioning and particle size distribution of legacy and current-use pesticides. Atmos. Chem. Phys. 16, 1531-1544.

Djaoudi, K., Barani, A., Helias-Nunige, S., Sempéré, R., Van Wambeke, F., Pulido-Villena, E., this issue. Atmospheric fluxes of soluble organic matter to the Mediterranean Sea: contribution to surface pool of dissolved organic matter.

Guieu, C., Loÿe-Pilot, M.-D., Benyahya, L., Dufour, A., 2010. Spatial variability of atmospheric fluxes of metals ( $\mathrm{Al}, \mathrm{Fe}, \mathrm{Cd}, \mathrm{Zn}$ and $\mathrm{Pb}$ ) and phosphorus over the whole Mediterranean from a one-year monitoring experiment: biogeochemical implications. Mar. Chem. 120, 164-178.

Han, C., Gu, X., Geng, J., Hong, Y., Zhang, R., Wang, X., Gao, S., 2010. Production and emission of phosphine gas from wetland ecosystems. J. Environ. Sci. (Chin.) 22 (9), 1309-1311.

Herut, B., Collier, R., Krom, M.D., 2002. The role of dust in supplying nitrogen and phosphorus to the Southeast Mediterranean. Limnol. Oceanogr. 47, 870-878.

Izquierdo, Rebeca, Benítez-Nelson, Claudia R., Masqué, Pere, Castillo, Sonia, Alastuey, Andrés, Àvila, Anna, 2012. Atmospheric phosphorus deposition in a near-coastal rural site in the NE Iberian Peninsula and its role in marine productivity. Atmos. Environ. 49, 361-370.

Karl David M., Björkman, Karin M., 2015. Dynamics of Dissolved Organic Phosphorus. Biogeochemistry of Marine Dissolved Organic Matter, pp. 233-334.

Koçak, M., Kubilay, N., Tugrul, S., Mihalopoulos, N., 2010. Atmospheric nutrient inputs to the northern Levantine basin from a long-term observation: sources and comparison with riverine inputs. Biogeosciences 7, 4037-4050.

Kouvarakis, G., Mihalopoulos, N., Tselepidis, A., Stavrakakis, S., 2001. On the importance of atmospheric inputs of inorganic species on the productivity of the Eastern Mediterranean Sea. Global Biogeochem. Cycles 15 (4), 805-817.

Kress, N., Herut, B., 2001. Spatial and seasonal evolution of dissolved oxygen and nutrients in the Southern Levantine Basin (Eastern Mediterranean Sea): chemical characterization of the water masses and inferences on the N:P ratios. Deep-Sea Res. I $48,2347-2372$

Krom, M.D., Kress, N., Brenner, S., Gordon, L.I., 1991. Phosphorus limitation of primary productivity in the eastern Mediterranean Sea. Limnol. Oceanogr. 36 (3), 424-432.

Krom, M.D., Herut, B., Mantoura, R.F.C., 2004. Nutrient budget for the Eastern Mediterranean: implications for P limitation. Limnol. Oceanogr. 49, 1582-1592.

Krom, M.D., Shi, Z., Stockdale, A., Berman-Frank, I., Giannakourou, A., Herut, B., Lagaria, A., Papageorgiou, N., Pitta, P., Psarra, S., Rahav, E., Scoullos, M., Stathopoulou, E., Tsiola, A., Tsagaraki, T.M., 2016. Response of the Eastern Mediterranean microbial ecosystem to dust and dust affected by acid processing in the atmosphere. Front. Mar. Sci. 3, 133. http://dx.doi.org/10.3389/fmars.2016.00133.

Lelieveld, J., Berresheim, H., Borrmann, S., Crutzen, P.J., Dentener, F.J., Fischer, H., Feichter, J., Flatau, P.J., Heland, J., Holzinger, R., Korrmann, R., Lawrence, M.G., Levin, Z., Markowicz, K.M., Mihalopoulos, N., Minikin, A., Ramanathan, V., de Reus, M., Roelofs, G.J., Scheeren, H.A., Sciare, J., Schlager, H., Schultz, M., Siegmund, P., Steil, B., Stephanou, E.G., Stier, P., Traub, M., Warneke, C., Williams, J., Ziereis, H., 2002. Global air pollution crossroads over the Mediterranean. Science 298, 794-799.

Longo, Amelia F., Ingall, Ellery D., Diaz, Julia M., Oakes, Michelle, King, Laura E., Nenes, Athanasios, Mihalopoulos, Nikolaos, Violaki, Kaliopi, Avila, Anna, Benitez-Nelson, Claudia R., Brandes, Jay, McNulty, Ian, Vine, David J., 2014. P-NEXFS analysis of aerosol phosphorus delivered to the Mediterranean Sea. Geophys. Res. Lett. 41. http://dx.doi.org/10.1002/2014GL060555.

Mahowald, N., Jickells, Timothy D., Baker, Alex R., Artaxo, Paulo, Benitez-Nelson, Claudia R., Bergametti, Gilles, Bond, Tami C., Chen, Ying, Cohen, David D., Herut, Barak, Kubilay, Nilgun, Losno, Remi, Luo, Chao, Maenhaut, Willy, McGee, Kenneth A., Okin, Gregory S., Siefert, Ronald L., Tsukuda, Seigen, 2008. The global distribution of atmospheric phosphorus deposition and anthropogenic impacts. Global Biogeochem. Cycles 22, GB4026. http://dx.doi.org/10.1029/2008GB003240.

Markaki, Z., Oikonomou, K., Kocak, M., Kouvarakis, G., Chaniotaki, A., Kubilay, N., Mihalopoulos, N., 2003. Atmospheric deposition of inorganic phosphorus in the Levantine Basin, Eastern Mediterranean: spatial and temporal variability and its role in seawater productivity. Limnol. Oceanogr. 48, 1557-1568.

Markaki, Z., Loÿe- Pilot, M.D., Violaki, K., Benyahya, L., Mihalopoulos, N., 2010. Variability of atmospheric deposition of dissolved nitrogen and phosphorus in the Mediterranean and possible link to the anomalous seawater N/P ratio. Mar. Chem 120, 187-194. http://dx.doi.org/10.1016/j.marchem.2008.10.005.

Marty, Jean-Claude, Chiavérini, Jacques, 2002. Seasonal and interannual variations in phytoplankton production at DYFAMED time-series station, northwestern Mediterranean Sea. Deep-Sea Res. II 49, 2017-2030.

Mather, Rhiannon L., Reynolds, Sarah E., Wolff, George A., Williams, Richard G., Sinhue Torres-Valdes, E., Woodward, Malcolm S., Landolfi, Angela, Pan, Xi, Sanders,
Richard, Achterberg, Eric P., 2008. Phosphorus cycling in the North and South Atlantic Ocean subtropical gyres. Nat. Geosci. 1, 439-443.

MerMex Group: X. Durrieu de Madron, C. Guieu, R. Sempere, P. Conan, D. Cossa, F. D'Ortenzio, C. Estournel, F. Gazeau, C. Rabouille, L. Stemmann, S. Bonnet, F. Diaz, P. Koubbi, O. Radakovitch, M. Babin, M. Baklouti, C. Bancon-Montigny, S. Belviso, N. Bensoussan, B. Bonsang, I. Bouloubassi, C. Brunet 1, J.-F. Cadiou, F. Carlotti, M. Chami, S. Charmasson, B. Charriere, J. Dachs, D. Doxaran, J.-C. Dutay, F. ElbazPoulichet, M. Eleaume, F. Eyrolles, C. Fernandez, S. Fowler, P. Francour, J.C. Gaertner, R. Galzin, S. Gasparini, J.-F. Ghiglione, J.-L. Gonzalez, C. Goyet, L. Guidi, K. Guizien, L.-E. Heimburger, S.H.M. Jacquet, W.H. Jeffrey, F. Joux, P. Le Hir, K. Leblanc, D. Lefevre, C. Lejeusne, R. Leme, M.-D. Loye-Pilot, M. Mallet, L. Mejanelle, F. Melin, C. Mellon, B. Merigot, P.-L. Merle, C. Migon, W.L. Miller, L. Mortier, B. Mostajir, L. Mousseau, T. Moutin, J. Para, T. Perez, A. Petrenko, J.-C. Poggiale, L. Prieur, M. Pujo-Pay, Pulido-Villena, P. Raimbault, A.P. Rees, C. Ridame, J.-F. Rontani, D. Ruiz Pino, M.A. Sicre, V. Taillandier, C. Tamburini, T. Tanaka, I. TaupierLetage, M. Tedetti, P. Testor, H. Thebault, B. Thouvenin, F. Touratier, J. Tronczynski, C. Ulses, F. Van Wambeke, V. Vantrepotte, S. Vaz, R. Verney, 2011. Marine ecosystems' responses to climatic and anthropogenic forcings in the Mediterranean. Prog. Oceanogr. 91, 97-166.

Migon, C., Sandroni, V., 1999. Phosphorus in rainwater: partitioning inputs and impact on the surface coastal ocean. Limnol. Oceanogr. 44 (4), 1160-1165.

Mihalopoulos, N., Stephanou, E., Pilitsidis, S., Kanakidou, M., Bousquet, P., 1997. Atmospheric aerosol composition above the Eastern Mediterranean region. Tellus 49B, 314-326.

Moral-Baquero, Rafael, Pulido-Villena, Elvira, Reche, Isabel, 2006. Atmospheric inputs of phosphorus and nitrogen to the southwest Mediterranean region: biogeochemical responses of high mountain lakes. Limnol. Oceanogr. 51 (2), 830-837.

Myriokefalitakis, S., Tsigaridis, K., Mihalopoulos, N., Sciare, J., Nenes, A., Kawamura, K., Segers, A., Kanakidou, M., 2011. In-cloud oxalate formation in the global troposphere: a 3-D modeling study. Atmos. Chem. Phys. 11, 5761-5782. http://dx.doi.org/ 10.5194/acp-11-5761-2011.

Nenes, A., Krom, M.D., Mihalopoulos, N., Van Cappellen, P., Shi, Z., Bougiatioti, A. Zarmpas, P., Herut, B., 2011. Atmospheric acidification of mineral aerosols: a source of bioavailable phosphorus for the oceans. Atmos. Chem. Phys. 11, 6265-6272.

Özsoy, T., 2003. Atmospheric wet deposition of soluble macro-nutrients in the Cilician Basin, northeastern Mediterranean Sea. J. Environ. Monit. 5, 971-976.

Pasqueron De Fommervault, Orens, Christophe, Migon, Aurélie, Dufour, Fabrizio, D’Ortenzio, Fayçal, Kessouri, Raimbault, P., Garcia, N., Véronique, Lagadec, 2015. Atmospheric input of inorganic nitrogen and phosphorus to the Ligurian Sea: data from the cap Ferrat coastal time-series station. Deep Sea Res. Part I 106, 116-125.

Pey, J., Querol, X., Alastuey, A., Forastiere, F., Stafoggia, M., 2013. African dust outbreaks over the Mediterranean Basin during 2001-2011: $\mathrm{PM}_{10}$ concentrations, phenomenology and trends, and its relation with synoptic and mesoscale meteorology. Atmos. Chem. Phys. 13, 1395-1410. http://dx.doi.org/10.5194/acp-13-1395-2013.

Richon, C., Dutay, J.-C., Dulac, F., Wang, R., Balkanski, Y., Nabat, P., Aumont, O. Desboeufs, K., Laurent, B., Guieu, C., Raimbault, P., Beuvier, J., 2017. Modeling the impacts of atmospheric deposition of nitrogen and desert dust-derived phosphorus on nutrients and biological budgets of the Mediterranean Sea. Prog. Oceanogr. http:// dx.doi.org/10.1016/j.pocean.2017.04.009.

Ridame, C., Guieu, C., Loÿe-Pilot, M.D., 1999. Trend in total atmospheric deposition fluxes of aluminium, iron and trace metals in the north-western Mediterranean over the past decade (1985-1997). J. Geophys. Res. 104 (D23), 30127-30138.

Standard Methods for the Examination of Water and Wastewater, 1998. American Public Health Association, 20th ed.

Stockdale, Anthony, Krom, Michael D., Mortimer, Robert J.G., Benning, Liane G., Carslaw, Kenneth S., Herbert, Ross J., Shi, Zongbo, Myriokefalitakis, Stelios, Kanakidou, Maria, Nenes, Athanasios, 2016. Understanding the nature of atmospheric acid processing of mineral dusts in supplying bioavailable phosphorus to the oceans. Proc. Natl. Acad. Sci. 113 (51), 14639-14644. http://dx.doi.org/10.1073/ pnas.1608136113.

Suzumura, Kamatani, 1993. Isolation and determination of inositol hexaphosphate in sediments from Tokyo Bay. Geochim. Cosmochim. Acta 2197-2202.

Thingstad, T.F., Zweifel, L., Rassoulzadegan, F., 1998. P limitation of heterotrophic bacteria and phytoplankton in the northwest Mediterranean. Limnol. Oceanogr. 43 (1), 88-94.

Vet, Robert, Artz, Richard S., Carou, Silvina, Shaw, Mike, Ro, Ch-Un, Aas, Wenche, Baker Alex, Bowersox, Van C., Dentener, Frank, Galy-Lacaux, Corinne, Hou, Amy, Pienaar, Jacobus J., Robert Gillett, M., Forti, Cristina, Gromov, Sergey, Hara, Hiroshi, Khodzher, Tamara, Mahowald, Natalie M., Mahowald, Nickovic, Rao, P.S.P., Reid, Neville W., 2014. A global assessment of precipitation chemistry and deposition of sulfur, nitrogen, sea salt, base cations, organic acids, acidity and $\mathrm{pH}$, and phosphorus. Atmos. Environ. 93, 3-100.

Zhu, Renbin, Glindemann, Dietmar, Kong, Deming, Sun, Liguang, Geng, Jinju, Wang, Xiaorong, 2007. Phosphine in the marine atmosphere along a hemispheric course from China to Antarctica. Atmos. Environ. 41, 1567-1573. 